\section{Sociétés: Revue}

\section{des Sciences}

\section{Humaines ef}

\section{Sociales}

\section{"Brésil - ferre de liens imaginaires"}

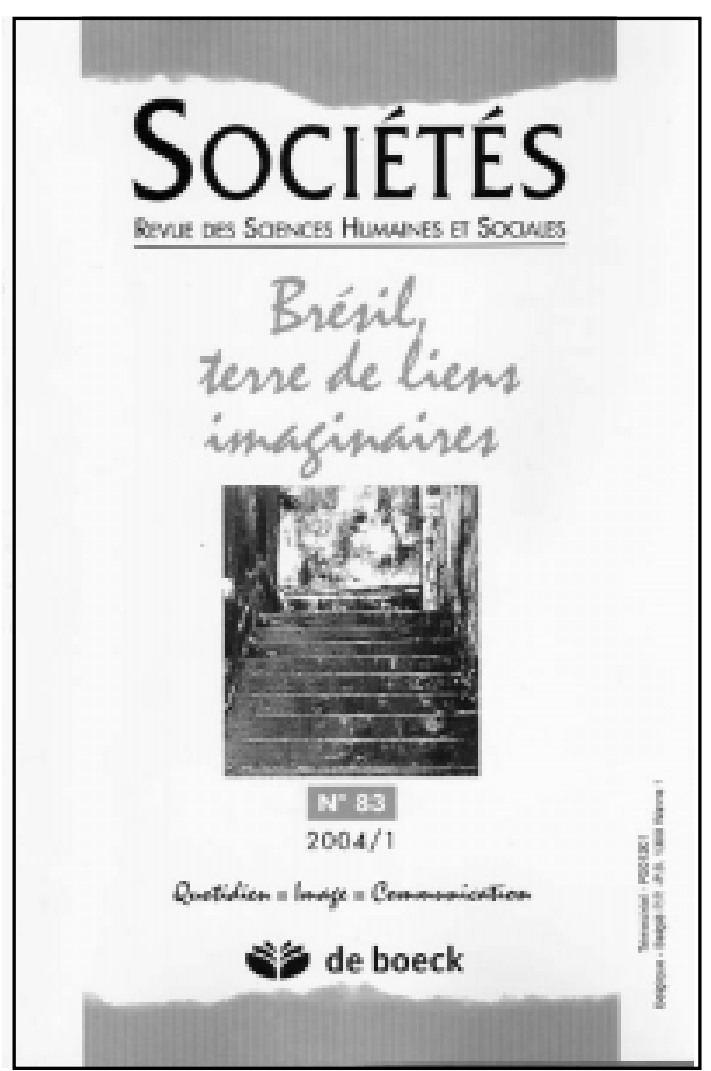

Juliana Tonin

Doutoranda do PPGCOM da PUCRS
“Estamos CADA VEZ MAIS confrontados por uma espécie de êxtase social. Que necessita ser, aqui, compreendido strictissimo sensu: sair de si e, por isso mesmo, paradoxalmente, unir-se à Alteridade" ${ }^{\prime 1}$. Através de um acordo de intercâmbio científico ocorrido entre Sorbonne-Paris V e o Programa de Pós-graduação em Comunicação Social da PUCRS, Michel Maffesoli, o pensador do tribalismo, do estar-junto, entrega a edição $\mathrm{n}^{\circ} 83$ da revista Sociétés: Revue des Sciences Humaines et Sociales, da qual é o diretor, à alteridade chamada Brasil. Sob o título "Brésil, terre de liens imaginaires", pesquisadores brasileiros, mais precisamente do programa de pós-graduação da PUCRS, tratam de expor suas pesquisas e compor as 115 páginas da revista. Cristiane Freitas Gutfreind e Juremir Machado da Silva, no texto de apresentação, retratam de forma geral o imaginário brasileiro, um Brasil no qual os mídias são as bacias semânticas. Para eles, o Brasil é uma constelação de identificações imaginárias tecida pelos mídias e pelas relações estabelecidas na busca pelo estar-junto: a rádio é a voz, a televisão é o espelho e a internet o novo brinquedo. Maria Beatriz Furtado Rahde e Flávio Vinícius Cauduro expõem um texto que procura compreender a arte contemporânea através da análise da obra da artista plástica gaúcha Vera Chaves Barcellos. Nele se pode verificar a ruptura de um modelo moderno da contemplação para a adesão aos valores da interação, uma mistura das técnicas no intuito de fazer valer a famosa noção de "obra aberta" de Umberto Eco. Neusa Demartini Gomes e Juliana Antonio- 
lli analisam a imagem do político através do marketing estratégico que reposicionou a imagem de Luiz Inácio Lula da Silva (Lula) contribuindo para ser eleito como presidente da República. Neste texto é possível conhecer um Brasil paradoxal: o desejo de eleger um representante do povo, mas não demasiadamente do povo. Antonio Hohlfeldt enfoca o romance folhetim na imprensa do sul do Brasil e estabelece uma ligação na qual tanto no Brasil, no sul do país, como na França este tipo de narrativa é o espelho das situações sociais vivenciadas em cada época. Ela propõe discussões acerca das situações polêmicas e serve como acelerador do desenvolvimento urbano. Beatriz Dornelles aborda o jornalismo engajado dos jornais de bairro presentes em vários estados brasileiros e aponta suas principais características no sul. É um jornalismo que procura atender às expectativas de uma comunidade específica, seja reivindicando soluções, perdurando tradições, costumes, auxiliando na oferta dos produtos e serviços presentes no local sempre num posicionamento "de dentro", ou seja, como se o jornalista fosse membro desta comunidade e tão responsável pela manutenção da mesma quanto qualquer habitante. São as tribos, os grupos que elegem seus pequenos líderes (neste caso uma mídia local) para realizar seus ideais comunitários. Maria Helena Steffens de Castro escreve sobre a Revista do Globo de Porto Alegre (1929 a 1967) na qual os anúncios publicitários começaram a sofrer as transformações de um desenvolvimento/aperfeiçoamento do setor e passaram a utilizar anúncios testemunhais e recursos literários. Eles se aproximavam das características da ficção, mas ao mesmo tempo esta técnica gerava maior credibilidade aos anúncios, pois os produtos eram testemunhados como participantes de momentos decisivos e marcantes da vida, reenviando os consumidores para a fantasia, o sonho, as fábulas e os poemas que poderiam se realizar no ato do consumo. Era a publicidade começando a se tornar a mito- logia da época. Ana Carolina Escosteguy traça um panorama das pesquisas de recepção no contexto brasileiro, explicando que foi a partir da obra de Jesus MartínBarbero que houve uma nova maneira de pensar a recepção, deixando de lado as velhas noções de alienação e passividade do receptor em consideração às mediações vividas por eles. $\mathrm{O}$ poder é considerado às mídias da mesma maneira que ao consumidor e são levados em consideração o cotidiano, as culturas, as tradições e as múltiplas atuações do indivíduo. Cleusa Maria Andrade Scroferneker estuda a comunicação organizacional e os diversos autores que a conceituam. Nota uma necessidade cada vez maior de evidenciar as inumeráveis possibilidades de interpretação existentes nas organizações, tanto pelas próprias organizações como para os pesquisadores. Eliana Pibernat Antonini, a partir das noções de leitor modelo de Umberto Eco e de dedução, indução e abdução de Pierce, evidencia a semiótica como muito mais do que um acessório do processo de comunicação, mas como principal via na construção do sentido, pois pensa a cultura como um sistema complexo de signos no qual o sujeito estabelece relações através de uma semiosis ilimitada.

Todos os temas abordados, arte, política, literatura, jornalismo, publicidade, organizações, estudos culturais, semiótica, tentam fazer conhecer um pouco mais do "Laboratório da Pós-modernidade", o país de contrastes, de paradoxos, de conflitos, de hibridismo racial, cultural, lingüístico, bem como refletir, mostrar a outras alteridades além do território os caminhos pelos quais o conhecimento científico está percorrendo. Partilhar as pesquisas, as noções, as suspeitas, as especulações através desta edição é eternizar o instante, lembrando que para Maffesoli a vida se faz eterna enquanto bem coletivo •

\section{Nota}

1MAFFESOLI, Michel. O Instante Eterno. São Paulo: Zouk, 2003. 